\title{
PENAMPILAN PRODUKSI TELUR PUYUH PADA KAPASITAS KANDANG YANG BERBEDA
}

\author{
Ir. Eddy Trijana Sudjani, MMa \\ Dosen Program Studi Ilmu Ternak Fakultas Peternakan \\ Universitas Islam Balitar \\ Jl. Majapahit No. 04 Kota Blitar
}

\begin{abstract}
The aim the research was to know the egg production quail's to the different cage capacity. The result of this research can be used to inform of people on egg production quail's to the different cage capacity. The materials of the reseach use 135 quail, cage system size $50 \mathrm{~cm} \mathrm{x}$ $50 \mathrm{~cm}$ front height $16 \mathrm{~cm}$ and back height $12 \mathrm{~cm}$. The research condcted by Completely Randomized Design (CRD) which is consist of three treatment and three replication and be continued Different Small Reallity (DSR). This research show that the cage capacity not significantly effect on production full fill by 20 quail; 15 quail; 10 quail production egg 348 , 304,$351 ; 264,252,229 ; 156,196,193$ and also gave not significanlya effect, and the rate feed are 9390, 9370, 9410; 7380, 7260, 7160; 4760, 4880, 4950 gave not significantly effect.
\end{abstract}

Key word: Quail, egg production, cage capacity

\section{Pendahuluan}

Peternakan merupakan sektor penyumbang terbesar dalam penyediaan kebutuhan pangan khususnya kebutuhan protein hewani. Kebutuhan protein hewani semakin meningkat seiring dengan pertambahan penduduk, meningkatnya pengetahuan, peningkatan pendapatan serta kesadaran akan pentingnya kebutuhan protein dalam kehidupan manusia. Puyuh sebagai salah satu ternak unggas cocok diusahakan baik sebagai usaha sambilan maupun komersil. Sebab, telur dan dagingnya semakin populer dan dibutuhkan sebagai salah satu sumber protein hewani yang cukup penting. Ditilik dari produksinya sebenarnya produksi telur burung ini cukup banyak dengan produksi telur 300 butir pertahun.

Secara garis besar yang mempengaruhi produksi telur adalah faktor genetik, ransum (kualitas dan konsumsi ), keadaan kandang, temperatur, penyakit dan stress (Anonymous, 2010). Pakan yang bagus akan menghasilkan telur yang bagus pula. Mencampur pakan dengan bekatul/dedak, jagung giling, dll. Percampuran pakan pabrikan dengan bahan-bahan alternatif tersebut akan menurunkan kualitas telur puyuh (Anonymous, 2011).Sebagai satu usaha yang berorientasi ekonomi, kandang harus dibuat dalam perhitungan yang mempertimbangkan aspek teknis, dimana dalam hal ini keleluasaan kandang digunakan secara optimal. Secara umum, ukuran kandang koloni bagi burung puyuh berukuran 1x1 meter, dengan tinggi sekitar $30-35 \mathrm{~cm}$. Untuk memudahkan pengambilan telur burung puyuh, sebaiknya lantai kandang dibuat agak miring sedikit sekitar 10-20 derajat. Untuk kepadatan kandang puyuh yang sudah bertelur adalah sekitar 50ekor $/ \mathrm{m}^{2}$.

Harjanto (2009) Puyuh memiliki beberapa kelebihan dibanding dengan ternak unggas yang lain yaitu cepat memproduksi telur ( umur 41 hari), efisien dalam menggunakan pakan, lebih kebal terhadap penyakit, pengeraman telur lebih singkat (16 sampai 17 hari ) dan biaya pemeliharaan tidak mahal. (Abdulmunif, 2009) menambahkan ternak puyuh sangat mudah 
pemeliharaanya, tidak banyak memerlukan tenaga dan biaya yang banyak/besar, tidak banyak menyita tempat,dapat menampung anak puyuh $100 / \mathrm{m}^{2}$ berumur $1-10$ hari dan 60 ekor $\mathrm{m}^{2}$ untuk puyuh berumur diatas 10 hari ; cepat berkembangbiaknya, sehingga kebutuhan daging keluarga cepat terpenuhi, disamping rasanya yang gurih seperti daging ayam dan entok, puyuh ini memiliki kadar/nilai gizi yang sangat tinggi.

Sistem kandang kandang puyuh lebih tepatnya kandang puyuh petelur dengan sistem battery biasa juga memakai istilah kandang teluran. Sebab sampai sekarang untuk puyuh layer belum pernah menemui ternakan puyuh dengan sistem litter, kecuali pada masa pembesaran DOQ bibit puyuh (Anonymous, 2012). Dalam penyusunan kandang battery banyak cara yang digunakan oleh para peternak, kandang ini berbentuk sangkar dengan dinding dan lantai terbuat dari kawat ram sehingga sirkulasi udara lebih lancar. Untuk menahan pengaruh udara dingin, kandang diberi pelapis dari terpal. Kandang sistem baterai ada dua macam: kontruksi miring dan kontruksi bertingkat (Harjanto, 2009). Kandang battery berupa kotak sangkar yang terbuat dari bambu dan rangkanya dari kayu. Dengan ukuran panjang $120 \mathrm{~cm}$, lebar $60 \mathrm{~cm}$ dan tinggi $180 \mathrm{~cm}$, sehingga untuk ukuran kandang tersebut tiap ruangan ini per-tingkat idealnya di-isi 30-40 ekor burung puyuh petelur (Ariefmas, 2011).

\section{Materi Dan Metode Penelitian}

Kegiatan penelitian ini dilaksanakan mulai tanggal 12 Februari 2012 sampai 3 Maret 2012 di peternakan puyuh Bapak Musidi yang berlokasi di Desa Gogodeso Kecamatan Kanigoro Kabupaten Blitar. Lokasi peternakan ini berjarak $100 \mathrm{~m}$ dari jalan raya sehingga segala bentuk kegiatan transportasi dapat berjalan dengan lancar. Disamping itu peternakan ini sudah dijangkau oleh aliran listrik dan sarana telekomunikasi yang merupakan salah satu faktor penting dalam mendirikan sebuah peternakan.

\section{Materi Penelitian}

Materi yang digunakan dalam penelitian ini adalah puyuh petelur periode layer yang berumur 24 minggu berjumlah 135 ekor. Kandang baterai yang digunakan untuk penempatan puyuh petelur dengan ukuran panjang $50 \mathrm{~cm}$ x lebar $50 \mathrm{~cm}$ x tinggi kemiringan depan $16 \mathrm{~cm}$ dan belakang $12 \mathrm{~cm}$. Pakan yang digunakan adalah BP 104 yang merupakan ransum komplit dan dapat langsung diberikan pada puyuh yang diproduksi oleh PT. Charoen Pokphand Indonesia Tbk.

\section{Metode Penelitian}

Metode yang digunakan dalam penelitian adalah metode eksperimental dengan menggunakan Rancangan Acak Lengkap (RAL) dengan 3 perlakuan dan 3 pengulangan. Data primer diperoleh dari pengamatan langsung dengan berpartisipasi langsung aktif di lapangan, sedangkan data sekunder diperoleh dari catatan yang ada di peternakan Bapak Musidi.

Hasil pengumpulan data dalam penelitian ini dianalisis secara statistik dengan menggunakan analisis ragam, apabila terdapat perbedaan nyata atau sangat nyata diantara perlakuan, lanjutkan dengan uji Beda Nyata Terkecil.

\section{Hasil Pengamatan Dan Pembahasan}

Perkandangan puyuh petelur tempat pelaksanaan penelitian adalah satu-satunya lokasi perkandangan yang dimiliki oleh Bapak Musidi, yang berada di Desa Gogodeso Kecamatan Kanigoro Kabupaten Blitar. Posisi perkandangan puyuh petelur membujur dari arah utara 
sampai selatan dengan sisi panjang menghadap arah barat dan timur, Hal ini sesuai dengan pendapat Malton (2005) yang menyatakan bahwa tingkat penyinaran matahari yang tinggi merangsang timbulnya kanibalisme, oleh karena itu bangunan kandang diatur membujur dari timur ke barat yakni bagian lebar kandang berada di sebelah barat dan timur. Kandang baterai yang digunakan untuk penempatan puyuh petelur dengan ukuran panjang $50 \mathrm{~cm}$ x lebar $50 \mathrm{~cm}$ $\mathrm{x}$ tinggi kemiringan depan $16 \mathrm{~cm}$ dan belakang $12 \mathrm{~cm}$. Besar atau ukuran kandang puyuh yang akan digunakan harus sesuai dengan jumlah puyuh yang akan dipelihara seperti unggas yang lainnya, maka perlakuan ukuran kandang bagi puyuh, adalah hal yang juga ideanya satu ekor puyuh dewasa membutuhkan luas kandang $0,025 \mathrm{~m}^{2}$ (Anonymous, 2011).

\section{Konsumsi Ransum dan Pemberian Air Minum}

Pemberian ransum puyuh diberikan 1 kali dalam sehari yaitu sebanyak $25 \mathrm{~g} / \mathrm{ekor} / \mathrm{hari}$ yang diberikan pada jam 6 pagi. Abidin (2003) menambahkan selain pakan yang berkualitas, jumlah pemberian pakan juga memegang peranan penting dalam pertumbuhan dan perkembangan puyuh. Kebutuhan pakan puyuh fase bertelur dimulai umur 6 minggu diberi pakan sebanyak 20g/ekor/hari dan ketika masa bertelur kebutuhan pakan sebanyak 2223g/ekor/hari (Anonymous, 2011). Tempat pakan puyuh terbuat dari potongan kayu yang dibentuk kotak dan diatasnya diberi kawat supaya pakan tidak tercecer. Anonymous (2011) Menyatakan pemberian pakan 1 kali pada pagi hari lebih bagus, dengan pertimbangan pada waktu pagi burung puyuh lebih lama puasanya dihitung sejak sore sampai semalaman. Pemberian ransum puyuh yaitu $25 \mathrm{~g} /$ ekor/hari. Ketika masa bertelur kebutuhan pakan sebanyak 22-23g/ekor/hari (Anonymous, 2011).

Pemberian air minum dilakukan secara terus-menerus atau adlibitum dengan tujuan agar ayam tidak mengalami dehidrasi. Hal ini sesuai dengan pendapat Rizal (2006) bahwa konsumsi air pada puyuh biasanya dua kali lebih banyak dibanding dengan konsumsi makanannya. Abidin (2003) Menambahkan Kekurangan atau kehilangan air sampai 20\% akan menyebabkan kematian.

\section{Konsumsi ransum terhadap kapasitas kandang yang berbeda}

Hasil analisis ragam terhadap konsumsi ransum terhadap kapasitas kandang yang berbeda. Konsumsi ransum terhadap kapasitas kandang yang berbeda dapat dilihat pada tabel 1.

Tabel 1. Konsumsi pakan terhadap kapasitas kandang yang berbeda terhadap Kapasitas Kandang yang berbeda selama penelitian (21 hari)

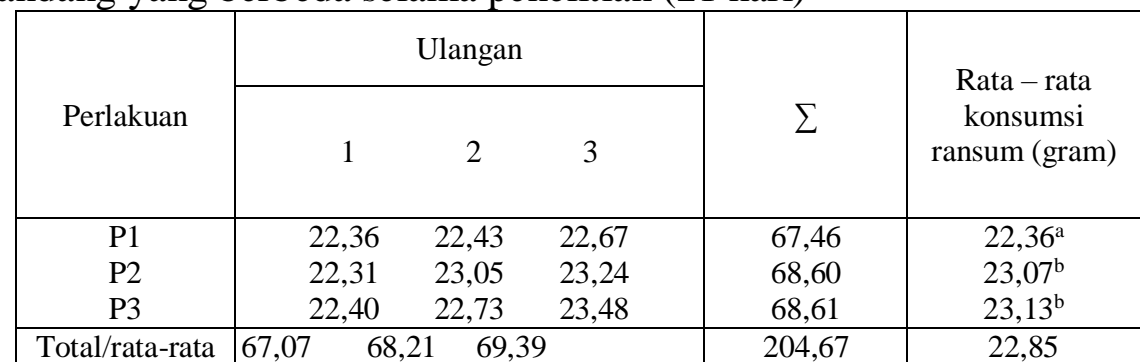

Keterangan: superskrip yang tidak sama pada kolom yang sama menunjukkan perbedaan yang berbeda antar perlakuan

Hasil analisis ragam pada lampiran menunjukkan bahwa kapasitas kandang yang berbeda memberikan perbedaan pengaruh yang tidak nyata terhadap pemberian ransum. Hasil uji BNT (Beda Nyata Terkecil) memberikan perbedaan yang sangat nyata. Hasil penelitian Andriyanto (1995), melaporkan bahwa kepadatan kandang yang rendah akan mengakibatkan 
timbulnya gangguan pada puyuh seperti stress, sehingga dapat mengakibatkan penurunan konsumsi pakan. Dengan kapasitas kandang yang berbeda dan pemberian ransum yang sama yaitu 25g/ekor/hari. Ketika masa bertelur kebutuhan pakan sebanyak 22-23g/ekor/hari (Anonymous, 2011).

Beberapa faktor yang mempengaruhi konsumsi pakan menurut Wahyu (1992) adalah bangsa puyuh, sistem kandang, temperature lingkungan, tahap produksi, periode pertumbuhan dan penyakit.

\section{Penampilan Produksi Telur Puyuh Dengan Kapasitas Kandang Yang Berbeda} tabel 2.

Produksi telur puyuh berdasarkan kapasitas Kandang yang berbeda dapat dilihat pada

Tabel 2. Produksi telur puyuh terhadap kapasitas kandang yang berbeda (21 hari)

\begin{tabular}{|c|ccc|c|c|}
\hline \multirow{2}{*}{ Perlakuan } & \multicolumn{3}{|c|}{ Ulangan } & \multirow{2}{*}{$\sum$} & $\begin{array}{c}\text { rata-rata } \\
\text { Telur } \\
\text { (butir) }\end{array}$ \\
\cline { 2 - 4 } & 1 & 2 & 3 & & $16,72^{\mathrm{a}}$ \\
\hline P1 & 17,4 & 17,6 & 15,6 & 50,6 & $16,56^{\mathrm{a}}$ \\
P2 & 15,2 & 16,8 & 19,6 & 51,6 & $18,17^{\mathrm{b}}$ \\
P3 & 17,55 & 15,27 & 19,3 & 52,12 & 17,56 \\
\hline Total & 50,15 & 49,67 & 54,5 & 154,32 & 17 \\
\hline
\end{tabular}

Hasil analisis ragam pada menunjukkan bahwa kapasitas kandang yang berbeda tidak memberikan perbedaan pengaruh yang nyata $(\mathrm{P}<0,01)$ terhadap produksi telur. Ariefmas ( 2010) menambahkan setiap puyuh dewasa membutuhkan ruangan seluas $200-225 \mathrm{~cm}^{2}$. Sehingga jika sangkar berukuran $1 \mathrm{~m}^{2}\left(100 \mathrm{x} 100=1 \mathrm{~m}^{2}\right)$ bisa memuat 40 ekor puyuh, Sedangkan satu sangkar kurang lebih $30 \mathrm{~cm}$ dan tidak boleh lebih dari $35 \mathrm{~cm}$. Sebab, jika lebih tinggi akan merangsang puyuh untuk meloncat - loncat. Saat meloncat itu kepalanya bisa luka karena terantuk langit - langit sangkar. Dari 3 perlakuan dengan kapasitas kandang yang berbeda yaitu dengan ukuran kandang batteray panjang $50 \mathrm{~cm} \times$ lebar $50 \mathrm{~cm}$ x tinggi kemiringan depan $16 \mathrm{~cm}$ dan belakang $12 \mathrm{~cm}$ yang diisi dengan 20ekor; 15ekor; 10ekor maka diperoleh hasil produksi yang paling baik dengan kapasitas kandang yang berisi 10 ekor.

\section{Kesimpulan Dan Saran}

Kesimpulan

Kesimpulan penelitaian diatas adalah kapasitas kandang puyuh yang berbeda tidak berpengaruh terhadap konsumsi ransum. Kapasitas kandang puyuh yang berbeda tidak berpengaruh terhadap performace produksi telur

Saran

Untuk menghasilkan penampilan produksi telur yang tinggi hendaknya dipilih puyuh petelur yang masih produktif dan ditempatkan pada kapasitas kandang yang leluasa untuk beraktifitas sehingga puyuh tersebut menghasilkan produksi telur yang tinggi.

\section{Daftar Pustaka}


Abidin, Zainal. 2003. Meningkatkan Produktifitas Ayam Ras Petelur. Agromedia Pustaka. Jakarta.

Abdulmunif, 2009. Puyuh. blogspot.com/0... 25 Januari 2012.

Ahmadi, 2008. Rekontruksi Kandang Sistem Terbuka Ke Kandang Tertutup. http://www.majalahfovet.com/2009/01/saatnya-rekontruksi-kandang openatau.html.25 Januari 2012.

Andriyanto, 1995. Pengaruh Bobot Badan Awal dan Tingkat Kepadatan Kandang Konsumsi Pakan, Pertambahan Bobot Badan, dan Konversi Pakan Pada Itik Mojosari Jantan Periode Grower. Skripsi, Fapet UB.

Anggorodi, H.R. 1995. Ilmu Makanan Ternak Unggas. UI-Press, Jakarta.

Anonymous, 2008.Perkandangan.http://anak kandang.multiply.com/journal/item/3/ tentang- ternak-unggas. 25 Januari 2012.

2009. Beternak Puyuh. www.ac.ad/../puyuh main.htm. 25 Januari 2012.

2010. Budidaya Burung Puyuh. www..disnak.jabarprov.go.id. 25 Januari2012 2011. Puyuh Jaya. Mitra-bisnis.tripod.com/puyuh.html. 25Januari2012

2011. Pemeliharaan Dan Pemberian Pakan Burung Puyuh. Agromaret.com 2012. Agritekno. tripod.com/standart_pakan.htm. 25Januari2012 Ariefmas. 2010. Kontruksi Sangkar Untuk Puyuh Petelur. http://ariefmas.wordpress.com 1 Juni 2012 2011. Puyuh. Wordpress.com/puyuh/25Januari 2011

Hanafiah, A.H., 2000. Rancangan Percobaan : Teori dan Aplikasi. Fakultas Pertanian, Universitas Sriwijaya, Palembang.

Harjanto. 2009. Beternak Puyuh. Deltamedia, Jakarta

Lusia, K.Anna. 2011. Puyuh. healt.kompas.com. 29 februari 2012

Malton, A.2005. Housing Of Animal Development In Agriculture Engenering Eiseiver. Amsterdam.

Redaksi Agromedia, 2002. Puyuh Si Mungil Penuh Potensi. Agromedia Pustaka, Jakarta.

Rizal, Y. 2006. Ilmu Nutrisi Unggas. Andalas University Press. Padang.

Shanaway, M. M 1994. Qual Production system. Food and AgricultureOrganization of United Natotion. Rome.

Sudarmono, AS. 2003. Pedoman Pemeliharaan Ayam Ras Petelur. Kanisius. Yogyakarta.

Sugiharto, R.E. 2005. Meningkatkan Keuntungan Beternak Puyuh. Agromedia 
Pustaka, Jakarta.

Wahyu, J., 1992. Ilmu Nutrisi Unggas. Gadjah Mada University Press. Yogyakarta. 